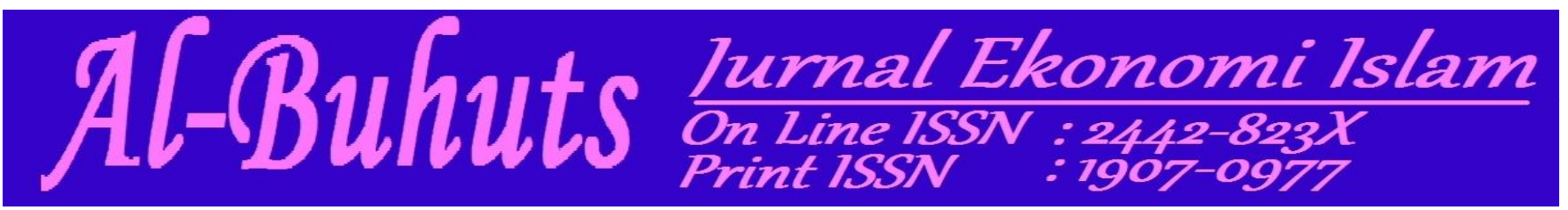

Volume. 14, Nomor 2, Desember 2018

\title{
Implementasi Keadilan dalam Pembangunan Ekonomi Islam
}

\author{
Desi Rahmiyanti, Siti Achiria \\ Email:desirahmianti@gmail.com, siti.achiria@uii.ac.id
}

\begin{abstract}
ABSTRAK
Penelitian ini dilatar belakangi adanya ketimpangan pendapatan yang berujung pada rendahnya kesejahteraan masyarakat. Tujuan penulisan untuk membuktikan implementasi keadilan dalam pembangunan ekonomi. Dengan menggunakan metode kualitatif dengan pendekatan literatur review yang di ambil dari beberapa referensi terkait, berupa jurnal maupun kitab-kitab klasik. Hasil dari kajian menjelaskan pembangunan ekonomi menurut ekonomi Islam, bukan sekedar terkait dengan peningkatan terhadap barang dan jasa. Islam tidak melihat pertumbuhan kekayaan sebagai sesuatu yang terpisah dengan cara distribusinya (pemerataan) dan tuntutan realisasi keadilan. Perkembangan ekonomi yang ideal akan mampu terwujud dengan optimal dan memiliki dampak terhadap pemerataan ekonomi jika tidak hanya dibutuhkan suatu pertumbuhan tetapi juga dibarengi dengan pemerataan. Dengan pemerataan perkembangan ekonomi yang adil akan meningkatkan kesejahteraan masyarakat.
\end{abstract}

Keyword: Perkembangan ekonomi, pemerataan ekonomi, keadilan

\section{Pendahuluan}

Pembangunan ekonomi adalah salah satu strategi untuk mencapai tujuan yang dicitacitakan bangsa ini. Pertumbuhan ekonomi, pendapatan perkapita penduduk, jumlah pengangguran, tingkat kemiskinan, dan neraca pembayaran adalah ukuran-ukuran yang dicapai dalam menilai tingkat keberhasilan pembangunan ekonomi.

Pembangunan ekonomi dewasa ini banyak ketergantungan kepada pertumbuhan ekonomi. Pertumbuhan ekonomi itu sendiri merupakan proses kenaikan produksi perekonomian suatu negara yang diwujudkan dalam bentuk kenaikanpendapatan nasional. ${ }^{1}$ Salah satu indikator terjadinya alokasi yang efisien secara makro adalah nilai output nasional yang dihasilkan sebuah perekonomian pada suatu periode tertentu. Jadi Salah satu indikator untuk mengukur

\footnotetext{
${ }^{1}$ Nurul Huda, (2015), EkonomiPembangunan Islam, Jakarta: Prenadamedia Group, hlm.77.
} 
Volume. 14, Nomor 2, Desember 2018

Hataman. 53-68
Implementasi Keaditan dalam Pembangunan Ekonomi Islam

pertumbuhan ekonomi adalah naik turunnya besaran pendapatan nasional atau Gross Domestic Product. $^{2}$

\section{Grafik PDRB Atas Dasar Harga Konstan 2010 di Indonesia Tahun 2011-2015}

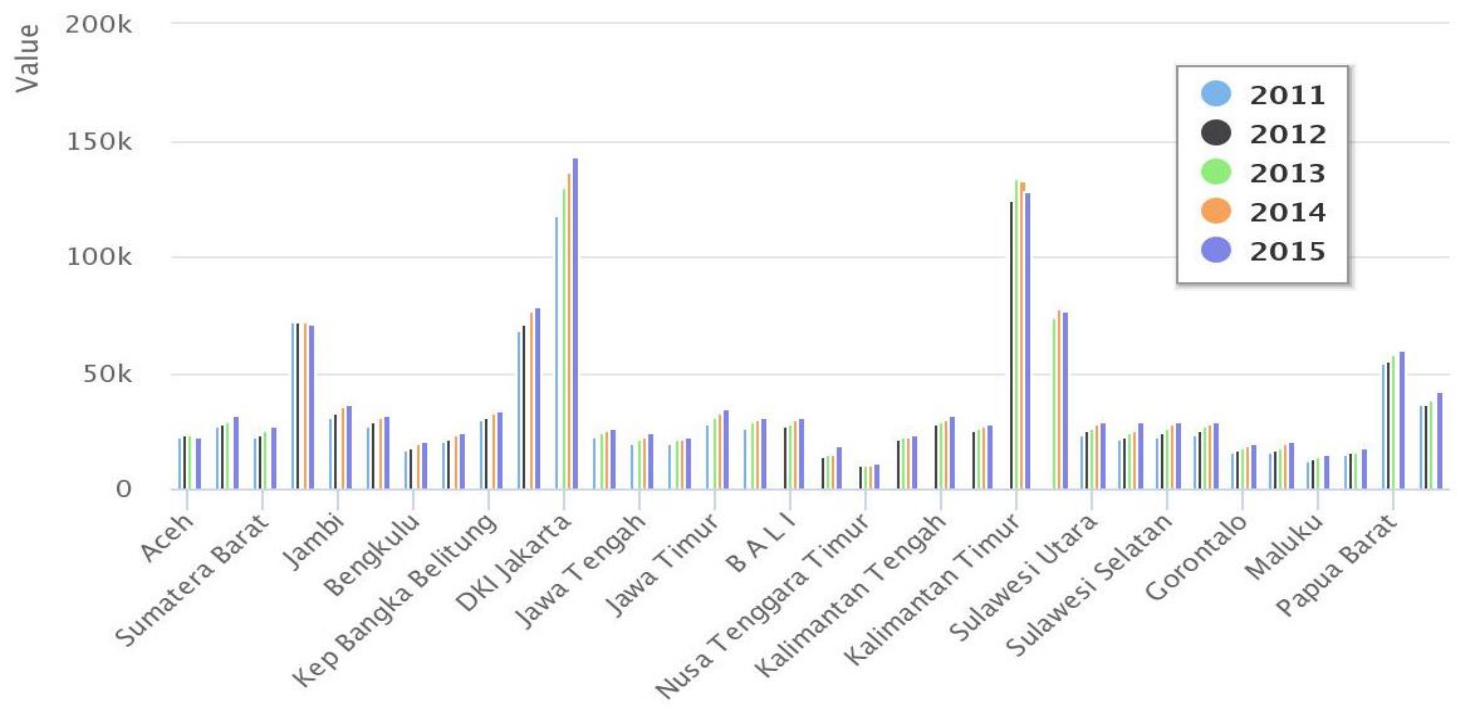

Sumber: Bappenas

Grafik di atas menunjukkan bahwa pertumbuhan ekonomi yang dilihat dari PDRB atas dasar harga konstan 2010 mengalami peningkatan setiap tahunnya. Hal tersebut menggambarkan bahwa Indonesia memiliki pertumbuhan ekonomi yang baik.

Selain itu bukti lain pertumbuhan ekonomi membaik adalah jumlah kemiskinan di Indonesia yang menurun, kemiskinan di Indonesia dari tahun ketahun jumlahnya fluktuatif, cenderung menurun namun perubahannya lambat dan pertumbuhan yang terjadi tidak secara merata.

${ }^{2}$ Rahardja, P. (2008). Pengantarlmuekonomi:mikroekonomidanmakroekonomi. Jakarta: fakultasEkonomiUniversitas Indonesia. Hlm. 5 
Volume. 14, Nomor 2, Desember 2018 Hataman. 53-68
Implementasi Keadilan datam Pembangunan Ekonomi Islam

\section{GrafikPresentasePendudukMiskin di Indonesia Tahun 2011-2015}

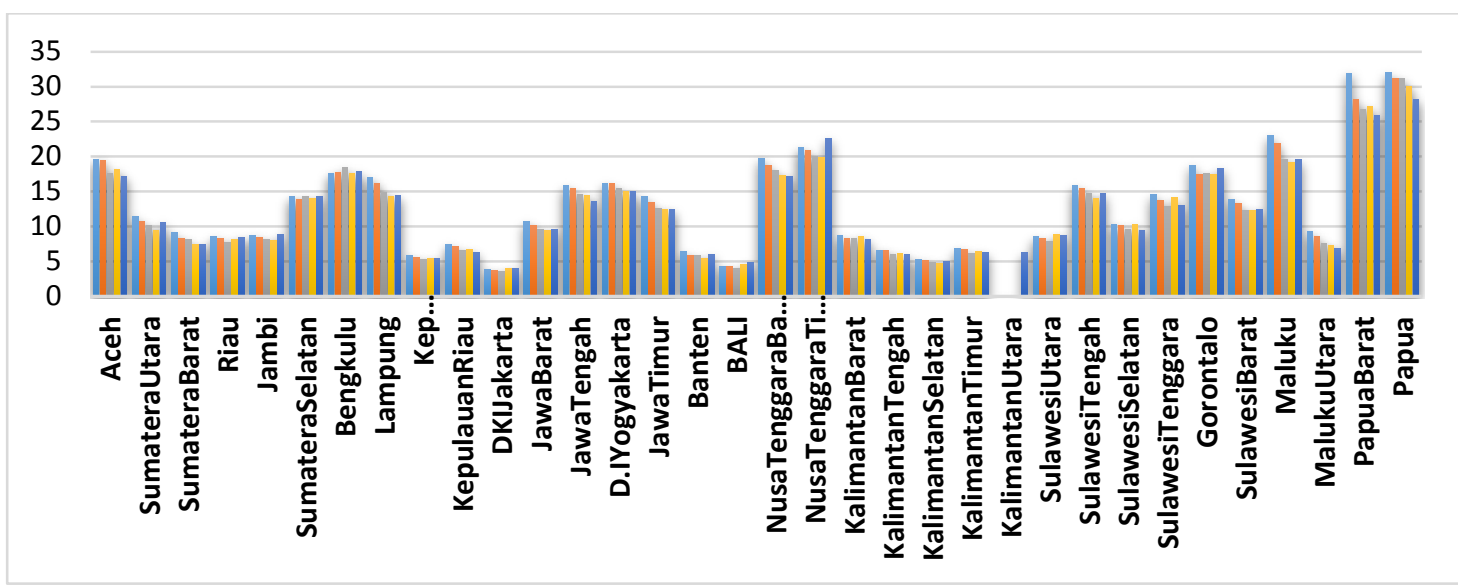

Sumber: Bappenas

Secara garis besar, tingkat kemiskinan di Indonesia pada tahun 2011-2015 mengalami penurunan setiap tahunnya. Meskipun persentase kemiskinan di Indonesia mengalami penurunan, tetapi penurunan kemiskinan tersebut tidak terjadi secara merata di setiap Provinsi, dalam waktu yang bersamaan kesenjangan penduduk miskin dan penduduk kaya di Indonesia tidak berubah, koefisien gini/rasio gini dalam lima tahun sejak 2010 sampai hingga 2015 tercatat 0,38;0,41; 0,$41 ; 0,42 ; 0,42 ;$ dan $0,42 .{ }^{3}$

\section{Grafik Gini Rasio di Indonesia Tahun 2011-2015}

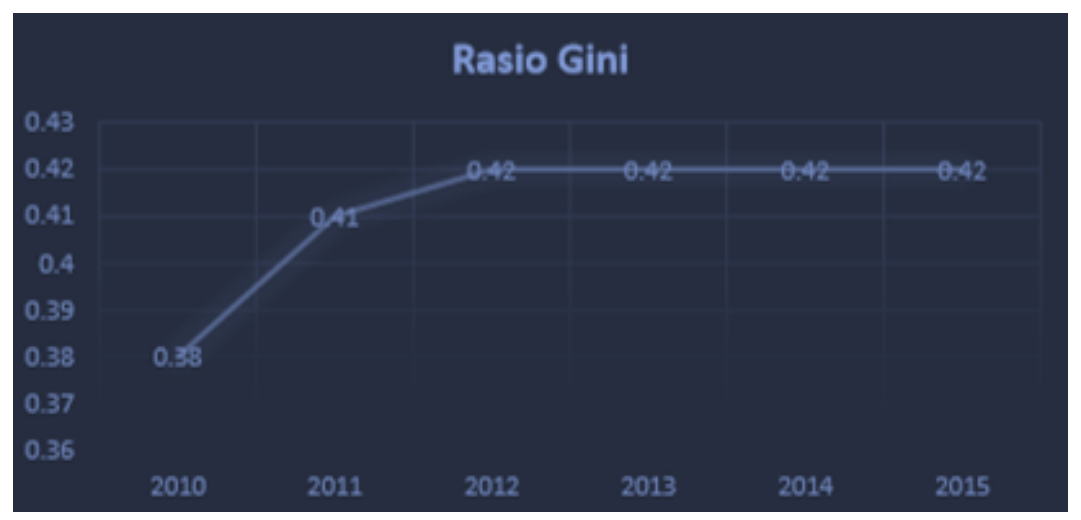

Sumber: BPS

\footnotetext{
${ }^{3}$ I. S. Beik, (2016),Ekonomi Pembangunan Syariah, Jakarta: Raja GrafindoPersada, hlm. 23
} 
Volume. 14, Nomor 2, Desember 2018

Hataman. 53-68
Implementasi Keadilan dalam Pembangunan Ekonomi Islam

Dari data tersebut terlihat bahwa ketimpangan ekonomi Indonesia cenderung meningkat dalam beberapa tahun terakhir. Dengan begitu, tidak sulit menggambarkan dengan jelas siapa yang sesungguhnya menikmati pertumbuhan ekonomikarena justru rata-rata gini rasio menunjukkan angka peningkatan.

Ini berarti pencapaian pendapatan domestik bruto (PDB) yang tinggi selama ini, ternyata masih tak mampu mewujudkan berbagai fenomena penting bagi kualitas hiduprakyat. Tak heran jika saat sebagian kalangan bangga dengan prestasi pertumbuhan PDB yang dicapai, mayoritas rakyat justru kurang merasakan manfaat dari pertumbuhan ekonomi yaitu adanya perbaikan taraf kehidupan.

Di satu sisi, pencapaian pertumbuhan mampu mengurangi tingkat kemiskinan dan memperbesar jumlah kelas menengah. Namun, di sisi lain juga mempelebar ketimpangan ekonomi. Menurut Bank Dunia, manfaat dari pertumbuhan ekonomi lebih dinikmati oleh 20\% masyarakat terkaya. Sementara sekitar $80 \%$ penduduk, lebih dari 205 juta orang terlihat merasa masih tertinggal. ${ }^{4}$

Kemudian hasil survei lain yang dipaparkan oleh Oxfam International pada Januari 2017, hasil riset tersebut menyatakan bahwa Indonesia berada pada peringkat keenam dalam kategori ketimpangan distribusi kekayaan terburuk di dunia. Selain itu Oxfam dalam laporannya menyatakan bahwa delapan orang terkaya memiliki kekayaan penduduk bumi, selama 15 tahun menunjukkan konsentrasi kekayaan di Indonesia dengan kelompok ultrakaya semakin bertambah kekayaannya. ${ }^{5}$

Berdasarkan uraian di atas maka diperlukan suatu pembahasan mengenai konsep keadilan dalam perkembangan ekonomi agar menjadi solusi untuk mengatasi permasalahan terkait kesejahteraan dan pemeratan ekonomi. Sebab pemerataan ekonomi merupakan hal yang sangat penting guna mewujudkan kesejahteraan. Namun dengan pola ekonomi saat ini yang menggunakan pola konvensional akan sulit mewujudkan pemerataan ekonomi untuk itu diperlukan kajian mengenai pembangunan ekonomi Islam.

\footnotetext{
${ }^{4}$ WorldBank. (2015). MeluasnyaKetimpangan di Indonesia. Retrieved from The World Bank: http://www.worldbank.org/in/n ews/feature/2015/12/08/indonesia-rising-divide

${ }^{5}$ OXFAM. (2017). Menuju Indonesia Yang LebihSetara:LaporanKetimpangan Indonesia. Retrieved from ISSUU: https://issuu.com/oxfaminindon esia/docs/report_indonesia
} 
Volume. 14, Nomor 2, Desember 2018

Hataman. 53-68
Implementasi Keadilan dalam Pembangunan Ekonomi Islam

\section{Pembangunan Ekonomi}

Pembangunan (development) mengandung pengertian suatu proses yang menyebabkan sesuatu dapat tumbuh (growth), atau menjadi lebih matang atau dewasa, lebih maju atau lebih terorganisasi. Secara konsep, pengertian pembangunan ekonomi memang sedikit berbeda dengan pertumbuhan ekonomi, namun walaupun telah dibedakan arti, pada akhirnya kedua istilah tersebut akan sering digunakan secara silih berganti.

Pembangunan ekonomi adalah suatu studi yang ditujukan untuk meningkatkan taraf hidup penduduk di negara-negara yang sedang berkembang, dengan memecahkan masalah-masalah utamanya yakni kemiskinan, pengangguran dan pemerataan. Pembangunan di negara-negara berkembang pada pelaksanaannya telah memunculkan pola, metode, atau model yang berbedabeda diantara mereka. Perbedaan ini telah menjadi paradigma atau pandangan yang mendunia dalam melaksanakan pembangunan. ${ }^{6}$

Dalam ekonomi pembangunan konvensional, isu utama dalam perekonomian adalah pertumbuhan. Pertumbuhan ekonomi selalu menjadi indikator kesejahteraan dan menjadi solusi bagi setiap krisis ekonomi. Pertumbuhan ini dipacu dengan peningkatan sumber daya terutama sumber daya manusia dan teknologi.?

Istilah pembangunan ekonomi (economic development) biasanya dikaitkan dengan perkembangan ekonomi di negara-negara berkembang. Sebagian ahli ekonomi mengartikan istilah ini sebagai "economic development is growth plus change" atau pembangunan ekonomiadalah pertumbuhan ekonomi yang diikuti oleh perubahan-perubahan dalam struktur dan corak kegiatan ekonomi. ${ }^{8}$

Indikator-indikator kunci pembangunan secara garis besar pada dasarnya dapat diklasifikasikan menjadi: indikator ekonomi, indikator sosial. Yang termasuk sebagai indikator ekonomi adalah: GNP (GNI) per kapita laju pertumbuhan ekonomi, GDP per kapita dengan

\footnotetext{
${ }^{6}$ Sadono Sukirno. (2009). EkonomiPembangunan,Proses, Masalah, danDasarKebijaksanaan. Jakarta: BimaGrafika. hlm. 35.

${ }^{7}$ F. Ulum, (2015),KonstruksiSistemEkonomi Islam MenujuKesejahteraan Yang Merata, TSAQAFAH, 3.

${ }^{8}$ Almizan, (2016),Pembangunan EkonomidalamPerspektifEkonomi Islam. MAQDIS: JurnalKajianEkonomi Islam, 204-222.
} 
Volume. 14, Nomor 2, Desember 2018

Hataman. 53-68
Implementasi Keadilan datam Pembangunan Ekonomi Islam

Purchasing Power Parity. Yang termasuk indikator sosial adalah HDI (Human Development Index) dan PQLI (Physical Quality Life Index) atau indeks Mutu Hidup. ${ }^{9}$

\section{Pembangunan Ekonomi Menurut Ekonomi Islam}

Paradigma sebagai ruang lingkup berpikir dan aktivitas menjadi variabel yang cukup signifikan dalam membedakan paradigma pembangunan ekonomi Islam. Perbedaan cara pandanglah yang memunculkan kesimpulan yang berbeda tentang paradigma pembangunan ekonomi. ${ }^{10}$ Dalam konteks pemikiran landasan pembangunan konvensional hanya mendasarkan materialistis, sistem nilai dan etika yang ditawarkan oleh Islam berbeda dengan yang diusung oleh kapitalisme dan sosialisme. Aspek spiritual menjadi dasar utama yang membedakannya. ${ }^{11}$ Adapun sistem ekonomi Islam berangkat dari way of life kesadaran tentang etika sebuah, ethical economy seorang muslim dalam berekonomi. Sedangkan sistem ekonomi lain, baik kapitalisme maupun sosialisme, berangkat dari kepentingan (interest). ${ }^{12}$

Pertumbuhan ekonomi dalam Islam, bukan hanya dalam persoalan ekonomi semata melainkan aktivitas manusia yang ditunjukkan untuk pertumbuhan dan kemajuan sisi materi dan spiritual manusia. ${ }^{13}$ Dilihat dari tujuan pokoknya, Islam tidak melihat pertumbuhan kekayaan sebagai sesuatu yang terpisah dengan cara distribusinya (pemerataan) dan tuntutan realisasi keadilan sosial. ${ }^{14}$ Pemerataan yang optimal apabila distribusi kebutuhan-kebutuhan individu telah berhasil dipenuhi secara memadai dan telah terwujud pembagian pendapatan dan kekayaan yang merata tanpa menngakibatkan efek samping yang buruk. Efisiensi pemerataan dalam distribusi tidak akan terwujud apabila moral tidak dibentuk.

Islam memiliki sistem ekonomi yang secara fundamental berbeda dari sistem-sistem yang tengah berjalan. Ia memiliki akar dan syariat yang membentuk pandangan dunia sekaligus sasaran-sasaran dan strategi (maqashidasy-syariah) yang berbeda dari sistem-sistem sekuler yang

\footnotetext{
${ }^{9}$ Mudrajat Kuncoro, (2010), Dasar-dasar Ekonomika Pembangunan, Yogyakarta: UPP STIM YKPN, hlm. 10.

${ }^{10}$ Nurul Huda, (2015), EkonomiPembangunan Islam, Jakarta: Prenadamedia Group, hlm.20.

${ }^{11}$ Ismail Nawawi, (2009),Pembangunan DalamPerspektif Islam,Surabaya: Putra Media Nusantara, hlm 25.

${ }^{12}$ Fadlan, (2010),Konsep Pembangunan EkonomiBerbasis Islam (SebuahUpaya Pembangunan Ekonomi Indonesia yang Adil, Makmur, dan Sejahtera), alIhkam, Vo 1.V N o .2, 259.

${ }^{13}$ A. A. Tariqi, (2004),Ekonomi IslamPrinsip, DasardanTujuan, Yogyakarta: MagistraInsania Press, hlm 24.

${ }^{14}$ Umar Chapra, (2000),Islam dan Pembangunan Ekonomi, Jakarta: GemaInsani, hlm. 34
} 
Volume. 14, Nomor 2, Desember 2018 Hataman. 53-68
Implementasi Keadilan dalam Pembangunan Ekonomi Islam

menguasai dunia hari ini. Sasaran-sasaran yang dikehendaki Islam secara mendasar bukan materiel. Mereka didasarkan atas konsep-konsep Islam sendiri tentang kebahagiaan manusia (falah) dan kehidupan yang baik (hayatan thayyibah) yang sangat menekankan aspek persaudaraan (ukhuwah), keadilan sosio-ekonomi, dan pemenuhan kebutuhan-kebutuhan spiritual umat manusia.

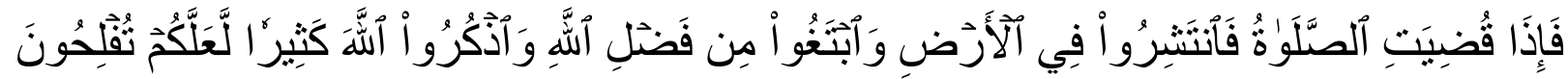

"Apabila telah ditunaikan shalat, maka bertebaranlah kamu di muka bumi, dan carilah karunia Allah dan ingatlah Allah sebanyak-banyaknya supaya kamu beruntung.” (QS. AlJumu'ah:10).

Selain dari dalil ayat alquran masih terdapat pula dalam hadist yang menjelaksan tentang keutamaan bekerja, diantaranya; "Tidaklah seorang di antara kamu, makan suatu makanan lebih baik daripada memakan dari hasil keringatnya sendiri” (HR. Baihaqi). Selanjutnya hadist yang diriwayatkan oleh ImamAhmad "Barangsiapa pada malam hari merasakan kelelahan dari upaya keterampilan kedua tangannya pada siang hari maka pada malam itu ia diampuni.”(HR. Ahmad).

Islam menganjurkan suatu sistem yang sangat sederhana untuk peningkatan ekonomi masyarakat yang membolehkan anggotanya melakukan proses pembangunan ekonomi yang stabil dan seimbang bebas dari kelemahan sistem kapitalis dan sosialis. Sistem ekonomi Islam menyediakan peluang-peluang yang sama dan memberikan hak-hak alami kepada semua (yaitu, hak terhadap harta dan bebas berusaha), dan pada saat yang sama menjamin keseimbangan dalam distribusi kekayaan, semata-mata untuk tujuan memelihara kestabilan dalam sistem ekonomi.

Selain itu pertumbuhan ekonomi menurut ekonomi Islam, bukan sekedar terkait dengan peningkatan terhadap barang dan jasa, namun juga terkait dengan aspek moralitas dan kualitas akhlak serta keseimbangan antara tujuan duniawi dan ukhrawi. Ukuran keberhasilan pertumbuhan ekonomi tidak sema-tamata dilihat dari sisi pencapain materi semata atau hasil dari kuantitas, namun juga ditinjau dari sisi perbaikan kehidupan agama, sosial dan kemasyarakatan. Jika pertumbuhan ekonomi yang terjadi justru memicu terjadinya keterbelakangan, kekacauan 
dan jauh dari nilai-nilai keadilan dan kemanusiaan, maka dipastikan pertumbuhan tersebut tidak sesuai dengan ekonomi. ${ }^{15}$

\section{Pemerataan Ekonomi}

Masalah pemerataan merupakan suatu hal yang kompleks, karena seringkali berkaitan dengan nilai-nilai sosial suatu masyarakat. Sebagian masyarakat memandang pemerataan sebagai suatu tujuan yang bernilai karena adanya implikasi moral dan hubungan yang erat dengan unsusr kelayakan keadilan sosial. Selain itu, masalah pemerataan juga berkaitan dengan upaya pengentasan kemiskinan, sehingga dapat meningkatkan kesejahteraan sosial masyarakat. ${ }^{16}$

Pemerataan distribusi pendapatan merupakan salah satu permasalahan pembangunan sebab pertumbuhan ekonomi tidak banyak bermanfaat terhadap peningkatan kesejahteraan masyarakat apabila distribusi hasil pembangunan tidak merata. Terdapat delapan penyebab ketidakmerataandistribusi pendapatan, diantaranya; pertumbuhan penduduk yang tinggi, in-lasi, pembangunan daerah tidak merata, penggangguran tinggi, mobilitas sosial rendah,memburuknya nilai tukar produk NSB, dan hancurnya industri kerajinan rakyat. ${ }^{17}$

Distribusi atau pembagian pendapatan antar lapisan masyarakat ditelaah dengan mengamati perkembangan angka-angka rasio gini. Namun koefisien ini sendiri bukanlah merupakan indikator paling ideal untuk mengukur ketidakmerataan distribusi pendapatan antar lapisan. Derajatketidakmerataan pendapatan dinyatakan dengan koefisien gini (Gini ratio, yang bernilai 0 (kemerataan sempurna sampai dengan 1 (ketidakmerataan sempurna).Sebaran gini ratio berkisar antara 0,50-0,70= ketidakmerataan tinggi, 0,36-0,49= ketidakmerataan sedang, dan 0,200,35 = ketidakmerataan rendah. koefisien gini dapat diperoleh dengan menghitung rasio bidang yang terletak antara garisdiagonal dan kurva loren dibagi dengan luas separuh bidang di mana kurva loren itu berada. Dalam ilmu ekonomi industri, koefisien gini juga dapat dipergunakan untuk melihat konsentrasi pasar. ${ }^{18}$

\footnotetext{
${ }^{15}$ I. S. Beik, (2016),Ekonomi Pembangunan Syariah, Jakarta: Raja GrafindoPersada, hlm. 44.

${ }^{16}$ Lincolin Arsyad, (2016), Ekonomi Pembangunan, Yogyakarta: UPP STIM YKPN, hlm. 284.

${ }^{17}$ Ibid., hlm. 283.

${ }^{18}$ Ibid., hlm. 86
} 
Volume. 14, Nomor 2, Desember 2018 Hataman. 53-68
Implementasi Keadilan dalam Pembangunan Ekonomi Islam

Ketidakmerataan distribusi pendapatan antar lapisan masyarakat bukansaja berlangsung secara nasional akan tetapi hal itu juga terjadi secara spasial atauantar daerah yakni antara daerah perkotaan dan pedesaan. Ketidakmerataan pendapatan yang berlangsung antar daerah tidak hanyadalam hal distribusinya, tapi juga dalam hal tingkat atau besarnya pendapatan itusendiri. Hal ini dapat dilihat dengan cara membandingkan persentase penduduk pedesaan terhadap penduduk perkotaan untuk tiap-tiap golongan pendapatan.

Pengangguran, kelangkaan barang, inflasi merupakan beberapa kriteria di mana proses distribusi pada suatu negara sedang memburuk. Sehingga tidak semua lapisan masyarakat dapat menikmati tingkat kesejahteraan dan kelayakan hidup yang adil, bahkan untuk memenuhi kebutuhan hidup minimumpun sangat sulit. Dengan demikian, jika kondisi tersebut terjadi, maka sistem ekonomi telah menyimpang dari salah satu tujuan penting Islam di dalam ekonomi yaitu keadilan sosial ekonomi dalam hal distribusi harta dan kekayaan di lapisan masyarakat. ${ }^{19}$

Islam menekankan distribusi pendapatan dan kekayaan yang adil, hingga setiap individu memperoleh jaminan serta tingkat hidup yang manusiawi dan terhormat, sesuai dengan harkat manusia yang inheren dalam ajaran-ajaran Islam, yaitu sebagai khalifah (wakil) Allah di muka bumi (QS. Al-Baqarah(2): 30):

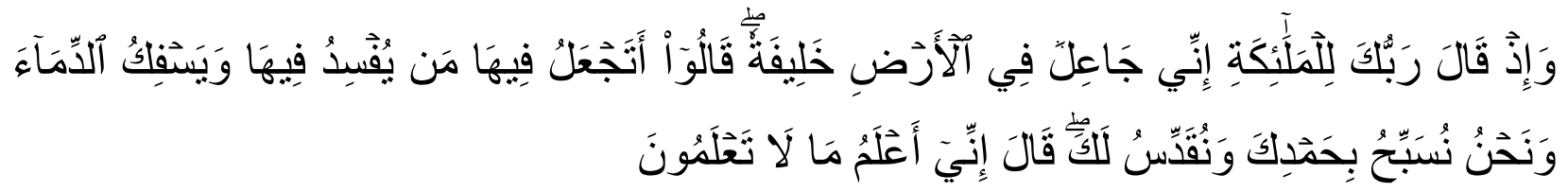

Artinya: "Ingatlah ketika Tuhanmu berfirman kepada para Malaikat: "Sesungguhnya Aku hendak menjadikan seorang khalifah di muka bumi". Mereka berkata: "Mengapa Engkau hendak menjadikan (khalifah) di bumi itu orang yang akan membuat kerusakan padanya dan menumpahkan darah, padahal kami senantiasa bertasbih dengan memuji Engkau dan mensucikan Engkau?" Tuhan berfirman: "Sesungguhnya aku mengetahui apa yang tidak kamu ketahui."

Kesejahteraan sosial memiliki tempat yang mutlak penting dalam Islam, dan kebebasan individu, walaupun sangat penting, tidak boleh mengabaikan implikasi sosialnya.Kebebasan

\footnotetext{
${ }^{19}$ Umar Chapra, (2000),Islam dan Pembangunan Ekonomi, Jakarta: GemaInsani, hlm. 40.
} 
Volume. 14, Nomor 2, Desember 2018 Hataman. 53-68
Implementasi Keadilan datam Pembangunan Ekonomi Islam

individu, dalam batas-batas etika Islam, hanya dianggap sah selama tidak bertentangan dengan kepentingan masyarakat yang lebih besar, atau selama individu yang bersangkutan tidak melanggar hak-hak orang lain. ${ }^{20}$

\section{Paradigma Keadilan Ekonomi Menurut Al-Qur'an}

Keadilan secara harfiah diartikan sebagai memberikan kepada semua yang berhak akan haknya, baik pemilik hak itu sebagai individu atau kelompok atau berbentuk sesuatu apa pun, bernilai apa pun, tanpa melebihi atau pun mengurangi. Tanpa melakukan pemihakan yang berlebihan, setidaknya dalam koridor konsep maupun premis, Islam mengajarkan tentang keadilan jauh lebih dahulu sebelum kaum konvensional meletakkan prinsip-prinsip keadilan dalam ekonomi. Islam telah memiliki dasar hukum yang kuat dalam pengaturan keadilan dan keseimbangan antara hak-hak dan kewajiban, antara individu dan masyarakat, antara rohani dan jasmani, dan antara dunia dan akhirat.

Di bawah sistem ekonomi Islam, penumpukan kekayaan oleh sekelompok orang dihindarkan dan langkah-langkah dilakukan secara otomatis untuk memindahkan aliran kekayaan kepada anggota masyarakat yang belum bernasib baik. Sistem ekonomi Islam merupakan sistem yang adil dan seksama serta berupaya menjamin kekayaan tidak terkumpul hanya kepada satu kelompok saja, tetapi tersebar diseluruh masyarakat ciri-ciri penting sistem ekonomi Islam tersebut digambarkan dalam ayat Al-Qur'an, yaitu dalam QS. Al-Hasyr (59) ayat 7:

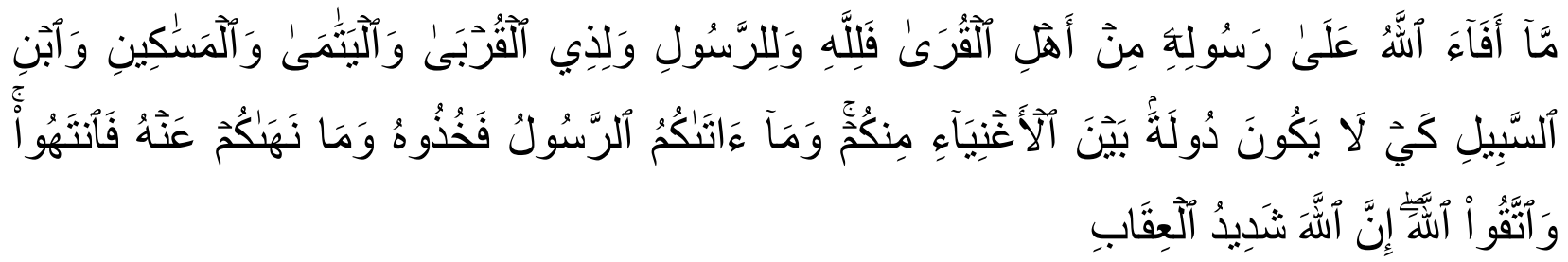

"Harta rampasan yang diberikan Allah kepada Rasul-Nya (yang berasal) dari penduduk beberapa negeri, adalah untuk Allah, Rasul, kerabat (Rasul), anak-anak yatim, orang-orang miskin dan untuk orang-orang yang dalam perjalanan, agar harta itu jangan hanya beredar diantara orang-orang kaya saja diantara kaтu. Apa yang diberikan Rasul kepadamu maka

\footnotetext{
${ }^{20}$ Nurul Huda, (2015), EkonomiPembangunan Islam, Jakarta: Prenadamedia Group, hlm.20.
} 
Volume. 14, Nomor 2, Desember 2018 Hataman. 53-68
Implementasi Keadilan dalam Pembangunan Ekonomi Islam

terimalah. Dan apa yangdilarangnya bagimu maka tinggalkanlah. Dan bertakwalah kepada Allah. Sungguh, Allah sangat keras hukuman-Nya."

Dalam sistem ekonomi Islam tidak terdapat individu-individu yang menjadi pengelola kekayaan negara ataupun sebaliknya semua individu secara paksa diletakkan pada tingkat ekonomi yang sama. Tetapi, kondisi tersebut diperbaiki supaya setiap individu tanpa mengganggu individu yang lain, dapat memperoleh kekayaan yang mencukupi untuk memenuhi kebutuhannya dengan cara yang baik. Individu akan mengeluarkan pendapatannya secara lebih ekonomis tanpa mengganggu keseimbangan ekonomi masyarakat keseluruhan. Dalam sistem tersebut, tidak ada kemungkinan untuk beberapa individu mengambil kesempatan mengumpulkan kekayaan secara berlebihan, sementara mayoritas rakyat dibiarkan susah payah dalam memenuhi keperluan pokok hidupnya. ${ }^{21}$

Untuk persoalan ekonomi, negara harus menjamin dan memastikan bahwa setiap warga negara memiliki kesempatan yang sama untuk mengakses dan memanfaatkan sumber daya ekonomi. Dampaknya, setiap anggota masyarakat akan dapat hidup dengan standar kebutuhan minimum, seperti makanan, tempat tinggal, kesehatan, pakaian, ibadah, dan pendidikan. Dengan demikian, negara selayaknya mengatur pemanfaatan sumber daya ekonomi tersebut agar dapat terdistribusi secara merata dan adil. Sehingga tidak ada satupun bagian dari anggota masyarakat yang terzalimi haknya baik oleh negara maupun sesama anggota masyarakat untuk memperoleh hak akses terhadap sumber daya ekonomi tersebut. ${ }^{22}$

Islam dalam menegakkan hukum-hukumnya didasarkan atas landasan keadilan di antara manusia. Allah telah memerintahkan untuk berbuat adil dalam banyak ayat Al-Qur'an. Allah berfirman dalam QS. An-Nahl (16) ayat 90:

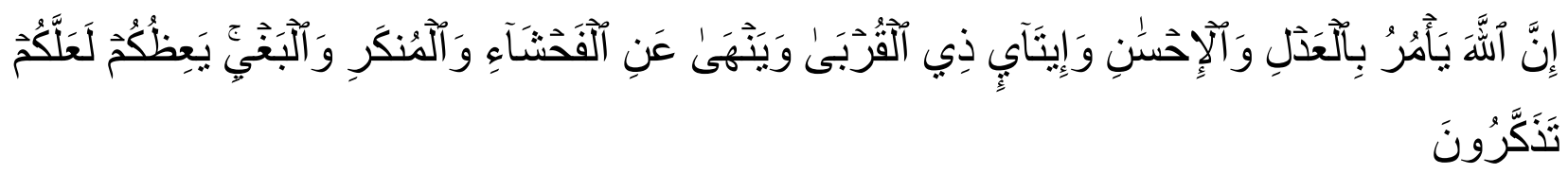

\footnotetext{
${ }^{21}$ Ibid., hlm.23.

${ }^{22}$ Ibid., hlm. 40.
} 
Volume. 14, Nomor 2, Desember 2018 Hataman. 53-68
Implementasi Keadilan dalam Pembangunan Ekonomi Islam

"Sesungguhnya Allah menyuruh (kamu) berlaku adil dan berbuat kebajikan, memberi kepada kerabat, dan Allah melarang dari berbuat keji, kemungkaran dan permusuhan. Dia memberi pengajaran kepada kamu agar mendapat pelajaran"

Selaras dengan hal ini, Ibrahim(2011) tujuan utama ekonomi pembangunan pada sistem ekonomi Islam adalah kesejahteraan manusia (human welfare). Proses pembangunan ekonomi dalam Islam menurutnya harus memanusiakan manusia. Ia harus terfokus terhadap pendidikan, mengutamakan integrasi sosial dan konservasi terhadap lingkungan. Baginya, pembangunan ekonomi harus berkelanjutan dan tidak melupakan generasi yang akan datang (future generation). ${ }^{23}$

\section{Implementasi Keadilan dalam Pembangunan Ekonomi di Indonesia}

Di Indonesia, strategi pembangunan yang diprioritaskan pada pemerataan hasil-hasil pembangunan dimulai sejak PELITA (Pembangunan Lima Tahun) III di era Soeharto. Ini sejalan dengan amanat GBHN bahwa arah dan tujuan pembangunan nasional Indonesia harus dapat dimanfaatkan bagi peningkatan kesejahteraan rakyat, dan hasil-hasil yang dicapai harus dapat dinikmati secara merata oleh seluruh rakyat Indonesia. Tujuan pembangunan tersebut erat kaitannya dengan upaya mengurangi kemiskinan dan kesenjangan pendapatan. ${ }^{24}$

Perkembangan distribusi pendapatan di Indonesia tergolong rendah selama 1976-2008 dengan menggunakan kriteria Bank Dunia. Pada tahun 1976, kelompok 40\% penduduk berpendapat terendah telah menerima 19,6\% dari pendapatan. Pada tahun 2008, kelompok, tersebut dapat menikmati $19,5 \%$ dari pendapatan. Dengan kata lain "kue pendapatan" yang menikmati $40 \%$ kelompok berpenghasilan terendah di Indonesia cenderung menurun selama 1976-2008.

Kendati ketimpangan distribusi pendapatan di Indonesia relatif rendah menurut standar Bank Dunia, ternyata porsi terbesar kue nasional tetap dinikmati $20 \%$ penduduk berpendapatan tertinggi dan $40 \%$ penduduk berpendapat menengah. Pada tahun 1976, kelompok $20 \%$ penduduk

${ }^{23}$ Ibrahim, Patmawati, SitiArniBasir, and Asmak Ab Rahman,(2011),Sustainable Economic Development: Concept, Principles and Management from Islamic Perspective, European Journal of Social Sciences, 24 (3): 330338.

${ }^{24}$ Lincolin Arsyad, (2016), Ekonomi Pembangunan, Yogyakarta: UPP STIM YKPN, Hlm. 85. 
Volume. 14, Nomor 2, Desember 2018 Hataman. 53-68
Implementasi Keadilan dalam Pembangunan Ekonomi Islam

berpendapat tertinggi telah menerima 42,5\% dari pendapatan; pada tahun 2008 kelompok tersebut dapat menikmati 44,2\% dari pendapatan. Pada tahun 1976, kelompok 40\% penduduk berpendapatan menengah telah menerima 38\% dari pendapatan; pada tahun 2008, kelompok tersebut dapat menikmati $35,6 \%$ dari pendapatan.

Proses ekonomi di Indonesia, selama pemerintahan orde baru dapat diambil kesimpulan bahwa etika sosial dan moralitas ekonomi tidak menjadi landasan dalam hubungan dan proses ekonomi. Terlihat dengan nayata bahwa, baik secara sadar maupun tidak telah didominasi oleh pemikiran ekonomi kapitalisme abad ke- 19. Terbukti dengan tumbuhnya secara kukuh kelas pemupuk rente dalam ekonomi Indonesia yang pada umumnya adalah konglemerat. ${ }^{25}$

Konsentrasi kekuasaan ekonomi ditangan para konglomerat terjadi sebagai akibat tidak adanya moralitas ekonomi atau etika sosial dalam hubungan dan proses ekonomi dalam mansarakat, kendatipun sudah termaktub dalam UUD 1945. Kelas pemupuk rente ekonomi menjalin hubungan yang simbiotis dengan elit kekuasaan dan para birokrat melalui hubungan yang simbiolis ini terjadilah apa yang disebut sebagai ditributional cualition. Kualisi ini merupakan suatu jaringan mirip kartel yang bertujuan meraih rente ekonomi semaksimum mungkin yang antara lain dilakukan dalam proses penguasaan aset-aset ekonomi melalui hak-hak istimewa bahkan secara tidak manusiawi (misalnya, tanah) atas nama pembangunan.

Pandangan Stiglitz (2002) yang dituangkan dalam Washington Consensus perlu kiranya dicermati, khususnya bagi pemerintah dalam usaha memperbaiki kinerjanya dalam menciptakan pembangunan ekonomi yang berkeadilan. Beliau menuangkan lima proporsi untuk memperbaiki kerja pemerintah dan tata pemerintah berdasarkan prinsip-prinsip dan instrumen ekonomi yang diturubkan dari nilai-nilai kebersamaan sebagai berikut:

1. Proporsi pertama, intervensi pemerintah dalam bidang yang secara nyata dan signifikan telah dipengaruhi oleh kepentingan kelompok tertentu harus dibatasi.

2. Proporsi kedua, tindakan pemerintah harus didorong untuk memajukan persaingan.

3. Proporsi ketiga, keterbukaan dalam pelaksanaan pemerintahan harus dikedepankan.

\footnotetext{
${ }^{25}$ Nurul Huda, (2015), EkonomiPembangunan Islam, Jakarta: Prenadamedia Group, hlm.116.
} 
4. Proporsi keempat, upaya penyediaan barang publik oleh institusi di luar pemerintah harus didorong sebagai mekanisme untuk menciptakan persaingan serta sarana penyaluran aspiratif yang efektif.

5. Propordi yang kelima, harus terdapat keseimbangan antara kepakaran dan partisispasi demokratis dan prinsip pertanggung gugatan dalam pengambilan keputusan.

Kelima proporsi tersebut merupakan acuan yang dapat diguanakan untuk memperbaiki kelemahan pemerintah. Memang banyak kelemahan pemerintah yang tetap tidak bisa diatasi, namun lima proporsi yang diajukan tersebut setidaknya dapat membuat respon masyarakat terhadap peran pemerintah menjadi lebih berimbang.

Dalam proses pembangunan ekonomi pada suatu lingkungan masyarakat dan elit kekuasaan yang berbudaya tinggi, sebenarnya dimensi keadilan merupakan sebuah dimensi yang tidak dapat terpisahkan. Dalam pengertian ini, proses pembangunan ekonomi yang tidak berdimensi keadilan dikategorikan sebagai proses yang anti pembangunan. Proses pembangunan dengan dimensi keadilan sebagai dimensi utama hanya dapat berlangsung secara efektif dan langgeng di dalam masyarakat jikalau sistem kemasyarakatan telah mengalami reformasi yang mendasar sehingga prinsip-prinsip keadilan mendasari interaksi antara anggota masyarakat.

Suatu ilusi bahwa proses pembangunan yang berkeadilan akan dapat berlangsung secara efektif dan permanen di dalam masyarakat apabila sistem sosial tidak mengandung basis-basis strategis kemasyarakatan yang kondusif untuk itu yang berkaitan dengan perilaku elit kekuasaan, dialektik hubungan ekonomi, dan sikap budaya rakyat, perubahan sosial yang mendasar mengandung pengertian yakni perubahan dimana mencangkup ketiga variabel kemasyarakatan tersebut. ${ }^{26}$

Proses pembangunan yang berdimensi keadilan selain tercermin pada tingkat ekonomi haruslah tercermin pada tingkat ekonomi mikro. Jikalau tidak, akan terperangkap ke dalam suatu sistem ekonomi dimana pemilik modal atau aset materiel secara sepihak akan menjadi penentu distribusi nilai tambah produk atau jasa yang diproduksi. Oleh sebab itu, sistem ekonomi yang demokratis secara nasional haruslah diikuti dengan terbentuknya unit-unit ekonomi yang demokratis ditingkat mikro.

\footnotetext{
${ }^{26}$ Ibid., hlm.117.
} 
Volume. 14, Nomor 2, Desember 2018

Hataman. 53-68
Implementasi Keaditan dalam Pembangunan Ekonomi Islam

\section{Kesimpulan}

Pertumbuhan ekonomi menurut ekonomi Islam, bukan sekedar terkait dengan peningkatan terhadap barang dan jasa, namun juga terkait dengan aspek moralitas dan kualitas akhlak serta keseimbangan antara tujuan duniawi dan ukhrawi. Kesejahteran dan Pertumbuhan Ekonomi yang ideal akan mampu terwujud dengan optimal dan memiliki dampak terhadap pemerataan ekonomi jika menggunakan prinsip ekonomi Islam yang menjamin kebutuhan pokok tiap individu rakyat bisa terpenuhi.

Dalam sistem ekonomi Islam tidak terdapat individu-individu yang menjadi pengelola kekayaan negara ataupun sebaliknya semua individu secara paksa diletakkan pada tingkat ekonomi yang sama. Tetapi, kondisi tersebut diperbaiki supaya setiap individu tanpa mengganggu individu yang lain, dapat memperoleh kekayaan yang mencukupi untuk memenuhi kebutuhannya dengan cara yang baik.

Tujuan utama ekonomi pembangunan pada sistem ekonomi Islam adalah kesejahteraan manusia (human welfare). Proses pembangunan ekonomi dalam Islam harus memanusiakan manusia. Ia harus terfokus terhadap pendidikan, mengutamakan integrasi sosial dan konservasi terhadap lingkungan. Baginya, pembangunan ekonomi harus berkelanjutan dan tidak melupakan generasi yang akan datang (future generation).

\section{Daftar Pustaka}

Arsyad,Lincolin.(2016).Ekonomi Pembangunan. Yogyakarta: UPP STIM YKPN.

Almizan. (2016).Pembangunan Ekonomi dalam Perspektif Ekonomi Islam. MAQDIS: Jurnal Kajian Ekonomi Islam, 204-222.

Badan Perencanaan Pembangunan Nasional. (2016). Pembangunan Daerah Dalam Angka 2016. Jakarta: Direktorat Pengembangan Wilayah.

Badan Pusat Statistik. (2016). Statistik Indonesia Tahun 2016. Jakarta: Badan Pusat Statistik

Beik, I. S. (2016).Ekonomi Pembangunan Syariah. Jakarta: Raja GrafindoPersada.

Chapra, Umar. (2000).Islam dan Pembangunan Ekonomi. Jakarta: GemaInsani. 
Volume. 14, Nomor 2, Desember 2018

Hataman. 53-68
Implementasi Keaditan dalam Pembangunan Ekonomi Islam

Fadlan. (2010).Konsep Pembangunan EkonomiBerbasis Islam (SebuahUpaya Pembangunan Ekonomi Indonesia yang Adil, Makmur, dan Sejahtera).allhkam, Vo 1.V N o .2, 259.

Huda, Nurul. (2015).EkonomiPembangunan Islam.Jakarta: Prenadamedia Group.

Ibrahim, Patmawati, SitiArniBasir, and Asmak Ab Rahman.(2011).Sustainable Economic Development: Concept, Principles and Management from Islamic Perspective. European Journal of Social Sciences, 24 (3): 330-338.

Kuncoro, Mudrajat. (2010). Dasar-dasar Ekonomika Pembangunan. Yogyakarta: UPP STIM YKPN.

Nawawi, Ismail. (2009).Pembangunan DalamPerspektif Islam. Surabaya: Putra Media Nusantara.

OXFAM. (2017). Menuju Indonesia Yang LebihSetara:LaporanKetimpangan Indonesia. Retrieved from ISSUU: https://issuu.com/oxfaminindon esia/docs/report_indonesia

Rahardja, P. (2008). PengantarIlmuekonomi:mikroekonomidanmakroekonomi. Jakarta: fakultasEkonomiUniversitas Indonesia.

Sukirno, Sadono. (2009). EkonomiPembangunan,Proses, Masalah, danDasarKebijaksanaan. Jakarta: BimaGrafika.

Tariqi,A. A. (2004).Ekonomi IslamPrinsip, DasardanTujuan. Yogyakarta: MagistraInsania Press.

Ulum, F. (2015).KonstruksiSistemEkonomi Islam MenujuKesejahteraan Yang Merata. TSAQAFAH, 3.

WorldBank. (2015). MeluasnyaKetimpangan di Indonesia. Retrieved from The World Bank: http://www.worldbank.org/in/n ews/feature/2015/12/08/indonesia-rising-divide. 